\title{
The benefic effect of Moroccan oil shale's ash on blended cement (CMII)
}

\author{
Nour El Houda Hamsi, Khadija Nabih* and Redwan Barbach \\ Mohammed V University, Faculty of Science, Department of chemistry, Rabat, Morocco \\ *khadijanabih@yahoo.fr
}

\begin{abstract}
Recycling of Tarfaya's oil shales (OSA) was conducted for two essential reasons: First, to follow the change of their mineralogical composition with the heat treatment and second to investigate the possibility of their use in building materials. The mineral compositions and the mineralogical transformations of the oil shale during their thermal treatment were followed respectively by X-ray fluorescence (XRF), by X-ray diffraction analysis (XRD) and Fourier transform infrared (FTIR). The $\mathrm{XRF}$ showed that the mineral composition of the ash burned at $850^{\circ} \mathrm{C}$ is similar to that of Portland clinker and the DRX showed the presence of quartz, mayenite, gehlenite, anydrite, hematite and lime as well as the existence of some characteristics phases of the clinker as $\mathrm{C}_{2} \mathrm{~S}, \mathrm{C}_{3} \mathrm{~A}$ and $\mathrm{C}_{4} \mathrm{AF}$. The Infrared spectrum showed the various functional groups that exist in OSA. The substitution of cement CMII by OSA increased the content of free lime and Blaine specific surface. The ash influenced beneficially the mechanical strength of the blended cement. The best results were obtained at all times of curing $(2,7,28$ and 91 Days) for the substitution of CMII by 7 and $10 \%$ of OSA.
\end{abstract}

\section{Introduction}

The substitution of a part of cement by thermal power plants wastes as fly ash or oil shale's ash provides multiple benefits. It reduces the consumption of nonrenewable natural raw materials [1] and the energy due to the fabrication of clinker, limits greenhouse gas emissions $\left(\mathrm{CO}_{2}\right)$, improves the quality of concrete and mortar by giving them a dense and compact microstructure, low permeability, low porosity and very good mechanical properties [2]. New technologies use OSA as additive or substitute to clinker or cement because of its availability as a by-product from the energy industry [3].

In this study, we are considering the use of Moroccan oil shale in cement. These shales are considered one of the largest energy and chemical resources in the world. They are estimated at several billions of oil barrels potentially exploitable. Their combustion for energy production will have a serious impact on the environment since one ton of oil shale produces 450-550 kilograms of ash $[4,5,6]$. Tarfaya's OSA is very promising to be used as additive to cement because its chemical composition is similar to that of Portland clinker [7].

\section{Materials and methods}

The raw materials used in the preparation of blended cements in this study are clinker, limestone, gypsum and OSA. These materials were crushed separately by a jaw crusher (old generation Fritsh pulverisette 01-703 type) to minimize their size.

The clinker was recovered from the cooler outlet of the plant. Limestone and gypsum were respectively dried in an oven respectively at $110^{\circ} \mathrm{C}$ for four hours and at $40^{\circ} \mathrm{C}$ for two hours.

The oil shales used in this study were taken from Tarfaya deposit (south of Morocco). The samples were donated by the National Office of Hydrocarbons and Mines (ONHYM). They were extracted into blocks of several kilograms, crushed and finely ground using a disc Mixer mill (Siebtechnik). The product was burned at $850^{\circ} \mathrm{C}$ for 30 minutes in a tubular laboratory furnace under atmospheric pressure, cooled down and sealed in plastic bags until its use in this study.

Clinker and raw materials included in the preparation of cements have been provided and prepared according to the method of standardized plant Asment (CIMPOR) [8].

The cement CMII was prepared in the laboratory through the normal processes involved in the plant. $75 \%$ clinker, $22 \%$ limestone and $3 \%$ gypsum were ground by a ball mill to fine powder in order to avoid any influence of the fineness on the mechanical properties of mortars. The refusal to $80 \mathrm{~nm}$ of cement was fixed between 1.8 and $2.7 \%$. 
In our case, the refusal of CMII was of $2.6 \%$. We varied the percentages of the shale ash in the cement by the substitution method (partial replacement of cement from $0 \%$ to $20 \%$ by the OSA). The oil shales and their ash were characterized by XRD, XRF. The Blaine surface areas were measured by the Blaine permeability apparatus. This measurement was based to determine the time required for a fixed volume of the air flow through a bed of powder. The density was determined by using Le Chatelier flask apparatus. This method was necessary to know the density as a part of the determination of the specific surface area.

The mechanical tests consisted in determining the resistance to compression and bending of prismatic specimens with dimension $4 \times 4 \times 16(\mathrm{~cm})$ according to the standards of the Asment plant [8]. These specimens were molded from a plastic mass containing a batch of mortar cement portion $(450 \mathrm{~g})$, three parts by weight of standard sand $(1350 \mathrm{~g})$ and a half part of water $(225 \mathrm{~g})$. The water / cement ratio was 0.5 .

The mortar was prepared by mechanical mixing with a mixer $(5 \mathrm{~L}$ capacity, $\mathrm{Vmin}=140 \mathrm{tr} / \mathrm{min}$ and $\mathrm{Vmax}=$ $285 \mathrm{tr} / \mathrm{min}$ ), filled into a mold $4 \times 4 \times 16$ and stored in a damp atmosphere $\left(\mathrm{T}=20 \pm 1^{\circ} \mathrm{C}\right.$ and humidity $\left.\leq 90\right)$ for 24 hours. After removal, the specimens were stored under water (wet cabinet) until resistance tests. The mechanical tests were carried at 2, 7, 28 and 91 days.

The free lime $\left(\mathrm{CaO}_{\text {free }}\right)$ determination was accomplished by using chemical analysis (Ethylene glycol method).

Analyses of the chemical and the mineralogical compositions of the all materials used in this study were investigated using respectively $\mathrm{X}$ ray fluorescence with Philips spectrometer PW 16660 device and X-rays diffraction with a Siemens D 5000 diffractometer.

The IR spectrum was recorded with a FTIR Bruker model Vertex 70 spectrometer by using the $\mathrm{KBr}$ pellet technique in the infrared region of $4000-400 \mathrm{~cm}^{-1}$.

Measurements of the expansion are performed using the needles of the normalized Le Chatelier according to the standard specifications [8]. The cement studied was tempered to normal consistency and introduced into small molds which were kept for 24 hours in water $\left(20 \pm 1^{\circ} \mathrm{C}\right)$. In order to observe the expansion of the cement in a short time, the reactions of hydration were accelerated by thermal treatment of the paste at $100^{\circ} \mathrm{C}$ for 3 hours.

\section{Results and discussion}

\subsection{Chemical analysis by X-ray fluorescence (XRF)}

\subsubsection{Chemical composition of raw materials}

The XRF analyzes showed the chemical composition of different materials used in the preparation of the blended cement studied. Table 1 shows the composition of the oil shale heated at $850^{\circ} \mathrm{C}$. The OSA is composed of major oxides, predominantly calcite and quartz with moderate amounts of $\mathrm{Al}_{2} \mathrm{O}_{3}$ and $\mathrm{Fe}_{2} \mathrm{O}_{3}$. This composition is almost similar to that of clinker CIMPOR whose composition is that of an ordinary Portland clinker. We also observed that the percentage of $\mathrm{SO}_{3}$ is very high for OSA. The same chemical analysis was performed for the gypsum to examine its degree of purity. The result showed that the purity of gypsum $\left(\mathrm{CaSO}_{4}, \mathrm{H}_{2} \mathrm{O}\right)$ used in this study was equal to $98.48 \%$, while its content of $\mathrm{SO}_{3}$ does not exceed $45.80 \%$.

\subsubsection{Chemical composition of different blended cements}

In this study, we varied the percentage of the addition of OSA in CMII by the partial substitution method to study their effects on the physicochemical properties of mortar.

From Table 2, we observed that the contents of the various major oxides $\left(\mathrm{SiO}_{2}, \mathrm{CaO}, \mathrm{Al}_{2} \mathrm{O}_{3}\right.$ and $\left.\mathrm{Fe}_{2} \mathrm{O}_{3}\right)$ in the blended cements were quite similar to that of CMII. These cements contained also minor oxides such as $\mathrm{MgO}$ (less than 5\%), $\mathrm{TiO}_{2}, \mathrm{~K}_{2} \mathrm{O}, \mathrm{P}_{2} \mathrm{O}_{5}, \mathrm{SO}_{3}$ (less than $4 \%$ [8]) and very low contents on $\mathrm{MnO}$ and $\mathrm{Na}_{2} \mathrm{O}$.

These minor oxides play an important role in the clinker burning process and they have an influence on the mechanical and physicochemical properties of cements. The metal ions of these oxides are present in different phases of the clinker and are therefore in the network of silicates, aluminates and alumino-ferrites either replacing the four major oxides or in interstitial sites [9].

The free $\mathrm{CaO}$ content was between 1.064 and $2.3 \%$ (must be less than $2 \%$ according to the standard Moroccan 10.1.004-2003). This explained the large speed of combination of $\mathrm{CaO}$ with other components of the mixture including silica [10]. The increase of free $\mathrm{CaO}$ can modify the mechanical properties of the cement. The formation of $\mathrm{Ca}(\mathrm{OH})_{2}$ can cause the swelling of the cement and consequently lower the mechanical resistances [11]. The addition of oil shale in the blended cement decreased the loss on ignition (L.O.I) which can improve the cement strength (the higher the L.O.I, the less strength the cement will develop (Table 2).

\subsection{Chemical Analysis X-ray diffraction (XRD)}

Figure 1 showed the $\mathrm{X}$-ray diffraction analysis of raw oil shale (a) and the calcined oil shale at $850^{\circ} \mathrm{C}$ (b). It can be seen from the figure 1 that, in the raw material there was a predominance of calcite $\left(\mathrm{CaCO}_{3}\right)$, followed by quartz $\left(\mathrm{SiO}_{2}\right)$ and dolomite $\left(\mathrm{CaMg}\left(\mathrm{CO}_{3}\right)_{2}\right)$. The latter occured in small quantity regarding the small peak and the small content of $\mathrm{MgO}$ confirmed by of X-ray fluorescence (Table 1).

At $850^{\circ} \mathrm{C}$, we observed a complete decomposition of dolomite, the appearance of new phases as hematite $\left(\mathrm{Fe}_{2} \mathrm{O}_{3}\right)$ and anhydrite $\mathrm{CaSO}_{4}$.

The decomposition of the dolomite gave rise to $\mathrm{MgO}$ and $\mathrm{CaO}$ oxides. The later was also produced by the decomposition of calcite according to the equations [7]:

$\mathrm{CaMg}\left(\mathrm{CO}_{3}\right)_{2} \rightarrow \mathrm{CaCO}_{3}+\mathrm{MgO}+\mathrm{CO}_{2}$

$\mathrm{CaCO}_{3} \rightarrow \mathrm{CaO}+\mathrm{CO}_{2}$ 
Table 1. Chemical analysis of raw materials given by x-ray fluorescence.

\begin{tabular}{|c|c|c|c|c|c|c|c|c|c|c|c|}
\hline Oxides & $\mathbf{S i O}_{\mathbf{2}}$ & $\mathbf{A l}_{\mathbf{2}} \mathbf{O}_{\mathbf{3}}$ & $\mathbf{F e}_{\mathbf{2}} \mathbf{O}_{\mathbf{3}}$ & $\mathbf{C a O}$ & $\mathbf{M g O}$ & $\mathbf{S O}_{\mathbf{3}}$ & $\mathbf{K}_{\mathbf{2}} \mathbf{O}$ & $\mathbf{T i O}_{\mathbf{2}}$ & $\mathbf{M n O}$ & $\mathbf{P}_{2} \mathbf{O}_{\mathbf{5}}$ & $\mathbf{L O I}^{\mathbf{a}}$ \\
\hline Limestone & 11.14 & 1.16 & 1.42 & 47.44 & 0.52 & 0.01 & 0.15 & 0.16 & 0.04 & 0.29 & 37.51 \\
\hline $\begin{array}{c}\text { Clinker } \\
\mathbf{C I M P O R}\end{array}$ & 20.11 & 4.86 & 3.40 & 64.96 & 3.17 & 1.60 & 0.88 & 0.34 & 0.09 & 0.25 & 0.22 \\
\hline $\begin{array}{c}\mathbf{O S A} \\
(\mathbf{8 5 0}\end{array}$ & 21.64 & 3.69 & 1.68 & 62.17 & 1.4 & 7.44 & 0.72 & 0.18 & 0.01 & 0.43 & 2.49 \\
\hline
\end{tabular}

a. loss on ignition

Table 2. Chemical analysis of different blended cement by x-ray fluorescence.

\begin{tabular}{|c|c|c|c|c|c|c|c|c|c|c|c|c|}
\hline Cements & $\mathrm{SiO}_{2}$ & $\mathrm{Al}_{2} \mathbf{O}_{3}$ & $\mathrm{Fe}_{2} \mathrm{O}_{3}$ & $\mathrm{CaO}$ & MgO & $\mathrm{SO}_{3}$ & $\mathbf{K}_{2} \mathrm{O}$ & $\mathrm{TiO}_{2}$ & MnO & $\mathbf{P}_{2} \mathbf{O}_{5}$ & LOI & $\begin{array}{c}\% \text { of } \\
\mathrm{CaO}_{\text {free }}\end{array}$ \\
\hline 0\% OSA & 18.76 & 4.48 & 2.91 & 58.05 & 2.91 & 2.06 & 0.70 & 0.33 & 0.08 & 0.22 & 9.43 & 1.064 \\
\hline $5 \%$ OSA & 18.03 & 3.99 & 2.87 & 59.67 & 2.42 & 2.21 & 0.66 & 0.30 & 0.08 & 0.27 & 9.08 & 1.13 \\
\hline $7 \%$ OSA & 18.65 & 4.24 & 2.94 & 58.90 & 2.45 & 2.26 & 0.68 & 0.30 & 0.08 & 0.27 & 9.11 & 1.23 \\
\hline $10 \%$ OSA & 18.39 & 4.43 & 2.83 & 59.03 & 2.40 & 2.45 & 0.66 & 0.29 & 0.07 & 0.27 & 8.82 & 1.736 \\
\hline $15 \%$ OSA & 18.27 & 3.92 & 2.75 & 59.43 & 2.34 & 2.72 & 0.68 & 0.29 & 0.07 & 0.28 & 8.64 & 2.07 \\
\hline $20 \%$ OSA & 18.76 & 4.02 & 2.76 & 59.37 & 2.32 & 2.82 & 0.70 & 0.29 & 0.07 & 0.28 & 8.4 & 2.3 \\
\hline
\end{tabular}
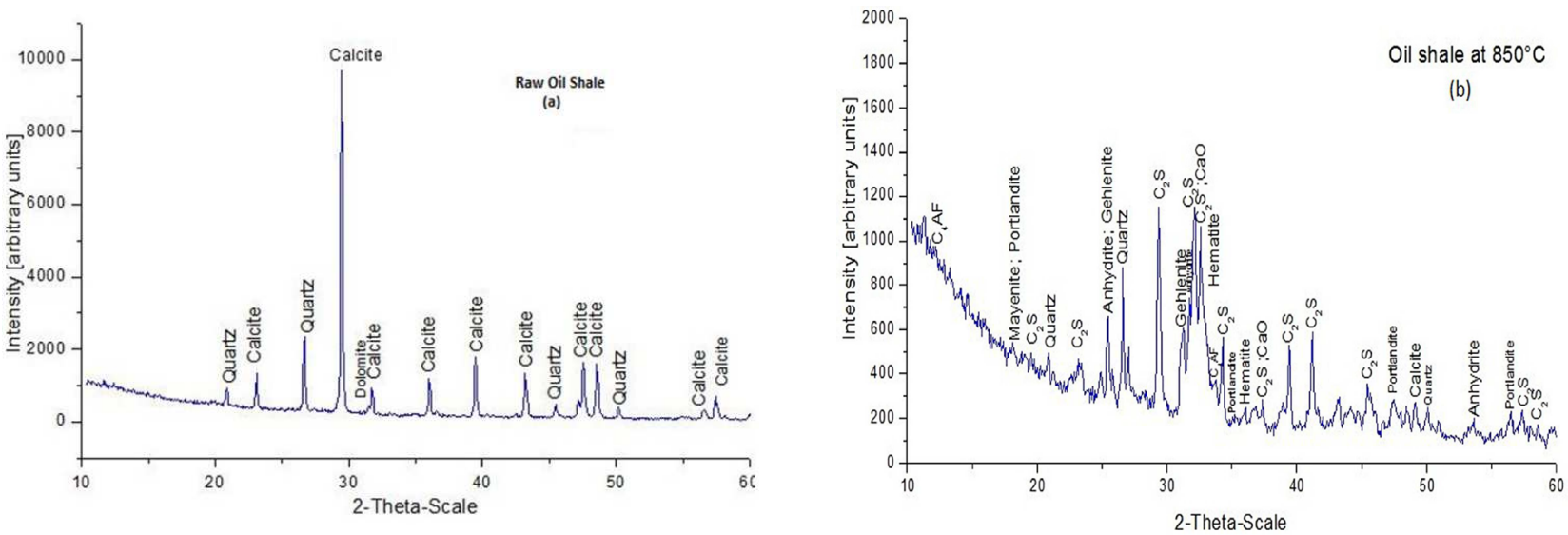

Fig. 1. X-ray Diffraction spectra of oil shale: (a) the raw oil shale and (b) the calcined oil shale ash at $850^{\circ} \mathrm{C}$.

The presence of anhydrite $\mathrm{CaSO}_{4}$ was due to the reaction of calcium oxide with sulfur dioxide that was released during the decomposition of the kerogen. The reaction equation is as follows:

$$
\mathrm{CaO}+1 / 2 \mathrm{O}_{2}+\mathrm{SO}_{2} \rightarrow \mathrm{CaSO}_{4}
$$

The formation of $\mathrm{CaSO}_{4}$, allows us to confirm that the sulfur was captured by calcium oxide. This result has been mentioned by other researchers [12-13]. They have reported that oil shales contained a large amount of calcite have a beneficial effect on the environment because $\mathrm{CaO}$ acted as a trap of $\mathrm{SO}_{2}$.
A great reduction of calcite and a considerable quartz peaks reduction were also observed.

These two oxides reacted together, and their reaction was confirmed by the existence of peaks characteristic of $\mathrm{C}_{2} \mathrm{~S}$ (belite) in the X-rays pattern.

We remark in the same spectre the presence of portlandite $\mathrm{Ca}(\mathrm{OH})_{2}$. The existence of this phase was probably due to exposure of the sample to atmospheric moisture.

The equation for the reaction between the free lime (formed because of the decomposition of calcite) and water is: $\mathrm{CaO}+\mathrm{H}_{2} \mathrm{O} \rightarrow \mathrm{Ca}(\mathrm{OH})_{2}$ 
we could also identify the presence of other phases namely hematite $\left(\mathrm{Fe}_{2} \mathrm{O}_{3}\right)$, the gehlenite $\left(\mathrm{Ca}_{2} \mathrm{Al}(\mathrm{AlSi}) \mathrm{O}_{7}\right)$ that normally forms around $800^{\circ} \mathrm{C}$ and there was also the appearance of the mayenite $\left(\mathrm{Ca}_{12} \mathrm{Al}_{14} \mathrm{O}_{33}\right)$, which was obtained by reacting the aluminum oxide $\left(\mathrm{Al}_{2} \mathrm{O}_{3}\right)$ with the calcium carbonate $\left(\mathrm{CaCO}_{3}\right)$, or with calcium hydroxide $\left(\mathrm{Ca}(\mathrm{OH})_{2}\right)[14]$.

\subsection{Fourier transforms infrared spectra (FTIR)}

The chemical groups present in OSA treated at $850^{\circ} \mathrm{C}$ were characterized by FTIR. As seen in the figure 2, the major bands of silicate group observed at 996, 993, 520 and $425 \mathrm{~cm}^{-1}$ were assigned to $\mathrm{SiO}_{2}$. The very strong peaks at 996,993 and $520 \mathrm{~cm}^{-1}$ were attributed to $\mathrm{Si}-\mathrm{O}$ stretching vibration. The medium band at $425 \mathrm{~cm}^{-1}$ was associated to $\mathrm{O}-\mathrm{H}$ stretching bands of $\mathrm{Si}-\mathrm{OH}$. Those peaks were respectively conducted from $\mathrm{C}_{2} \mathrm{~S}[15,16,17]$.

The absorption band at $3637 \mathrm{~cm}^{-1}$ can be attributed to portlandite $\left(\mathrm{Ca}(\mathrm{OH})_{2}\right)$, which was well detected in the sample and it was due to the $\mathrm{O}-\mathrm{H}$ stretching vibration $[18,19]$. The spectral bands in the region $3500-3400 \mathrm{~cm}^{-1}$ and the sharp peak at $1622 \mathrm{~cm}^{-1}$ were assigned to $\mathrm{OH}$ vibration of water molecules. The absorption bands at 1518 and $1414 \mathrm{~cm}^{-1}$ were attributed to $\mathrm{CO}_{3}{ }^{2-}$ stretching vibrations (the characteristic peak of calcite $\left(\mathrm{CaCO}_{3}\right)$ ). This peak is associated with the one at $847 \mathrm{~cm}^{-1}$ [20]. The presence of $\mathrm{CaCO}_{3}$ was attributed to the atmospheric $\mathrm{CO}_{2}$ absorption [21].

The strong absorption bands observed in 1137,1124 $\mathrm{cm}^{-1}$ and the weak vibration band at $643 \mathrm{~cm}^{-1}$ represented the stretching vibration of the sulfate group $\left(\mathrm{SO}_{4}{ }^{2-}\right)$ $[22,23,24]$. These results of FTIR analysis are consistent with the results found in the previous analysis.

\subsection{Expansion}

The expansion will ensure the stability of cement by determining the swelling of pure cement paste in a humid environment. Cements that contain too much of expansive components such as gypsum, free lime and magnesia can provoke dangerous expansion, cracking, distortion and disintegration with time for the durability of structures [25].

In this study, we can see from the Table 3 that there was an increase of expansion and of free lime by increasing the substitution of CMII by OSA.

The increase of the expansion is either due to the content of free lime or to the $\mathrm{SO}_{3}$ [26] or to both oxides that increased with the increase of OSA. In this study, the expansion did not exceed $11 \mathrm{~mm}$ even with $20 \%$ of Tarfaya's OSA (the Moroccan standard (NM 10.1.004) value for the expansion is $10 \mathrm{~mm}$ ).

\subsection{Fineness of cements with additions of OSA (Blaine)}

The measurements of specific surface areas (Table 4) were performed for the ash and for the different cement samples prepared with various percentages of OSA.
From Table 5, we noticed that the values of the specific surface area had increased with the substitution of CMII by OSA that have a low fineness. This Fineness can have an impact on the hydration of the blended cement.

Indeed, the specific surface area plays a decisive role in the evolution of the physical characteristics of cements prepared. The study showed that increase of the fineness increases the wetting of the cement grains, which improved the hydraulic reactivity. It has been shown by several authors that when the Blaine fineness of cement was higher, the hydration speed was faster and the mechanical strengths at early ages were excellent [27]. The plasticity and the cohesion of the fresh cement paste as well as its water retention capacity were influenced by the Blaine fineness [27].

\subsection{Bending and compressive strength behaviour}

The effects of the substitution of cement CMII by OSA on the bending and compression strength of mortars prepared at different ages 2, 7, 28 and 91 days are shown in the figures 3 and 4.

We noted an increase in the flexural and compressive strengths starting for young ages ( 2 and 7 days). This improvement of the strength was even greater at 28 and 91 days for various mortars with the addition of 5 to $20 \%$ of OSA.

Based on those results, it was concluded that the strengths increased with the increase of the curing time for the various blended cements. This was may be due to the increase of the amount of hydration products especially calcium silicate hydrates [28].

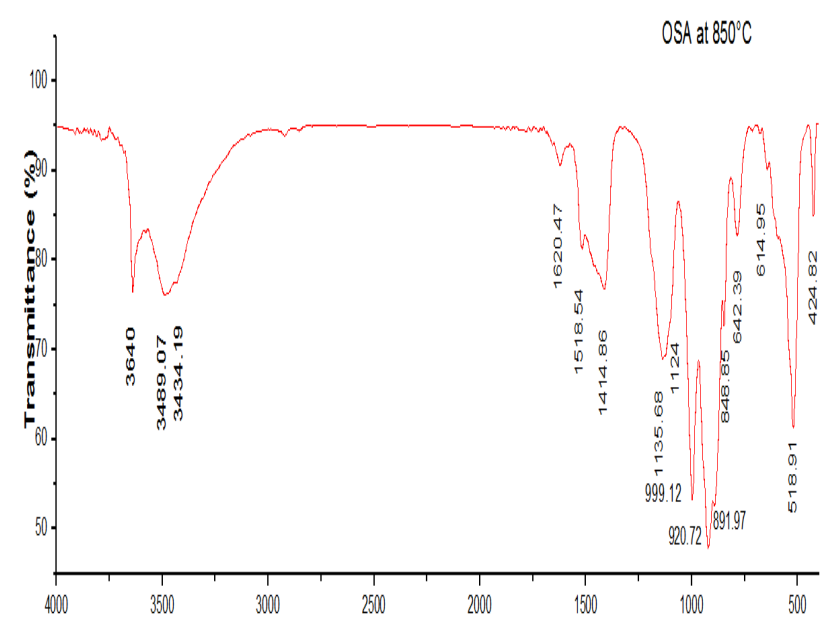

Fig.2. FTIR Spectra of oil shale heated at $850^{\circ} \mathrm{C}$. 
Table 3. Expansion values for cements as a function of the free lime.

\begin{tabular}{|c|c|c|c|c|c|c|}
\hline \% of OSA & 0 & 5 & 7 & 10 & 15 & 20 \\
\hline \% of CaO free & 1.06 & 1.13 & 1.23 & 1.74 & 2.07 & 2.3 \\
\hline $\begin{array}{c}\text { Expansion } \\
\text { (mm) }\end{array}$ & 1 & 1 & 3 & 9 & 10 & 11 \\
\hline
\end{tabular}

Table 4. Characteristics of OSA

\begin{tabular}{|c|c|c|c|}
\hline $\begin{array}{c}\boldsymbol{\rho} \\
\left(\mathbf{g} / \mathbf{c m}^{\mathbf{3}}\right)\end{array}$ & Density & $\begin{array}{c}\text { Surface area } \\
(\mathbf{c m} 2 / \mathbf{g})\end{array}$ & \% CaO free \\
\hline 3.09 & 3.63 & 4622 & 4.256 \\
\hline
\end{tabular}

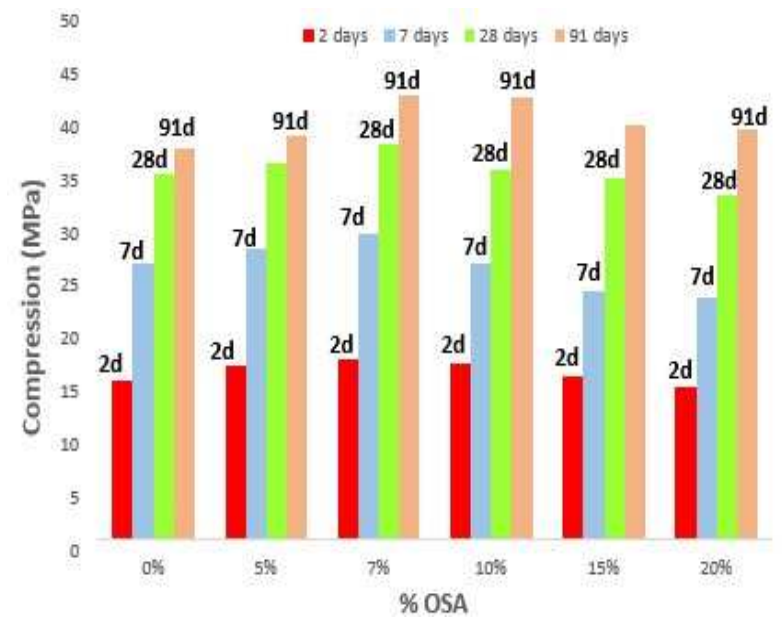

Fig.3. Compression strength of blended cement as a function of ash content.

\section{Conclusions}

The chemical compositions of the materials used in this study (oil shale burned at $850^{\circ} \mathrm{C}$ and the raw materials used for the elaboration of CMII) were given by the XRF analysis. From the chemical compositions, we noticed that oil shale's ash has a similar composition to those of Portland clinker, which gave these ashes good hydraulic and pozzolanic properties.

The results obtained by the X-ray diffraction showed that the mineral part of Tarfaya's oil shale was composed essentially of quartz, calcite, and dolomite their ash treated at $850^{\circ} \mathrm{C}$ contained anhydrite, muscovite, gehlenite, hematite with some of clinker phases such as: belite, alumino-silicate and ferrite with other minor mineralogical phases.

The substitution of CMII by OSA increased free lime content and the Blaine specific surface area and lead to small increase in the expansions without exceeding the one required by the Moroccan standard NM 10.1.004.
Table 5. Effects of Substitution CMII by ash on Blaine surface area of blended cements.

\begin{tabular}{|c|c|c|c|c|c|c|}
\hline \% OSA & 0 & 5 & 7 & 10 & 15 & 20 \\
\hline $\begin{array}{c}\text { Surface } \\
\text { area } \\
\left(\mathbf{c m}^{2} / \mathbf{g}\right)\end{array}$ & 3594 & 4542 & 4610 & 4733 & 5333 & 5343 \\
\hline
\end{tabular}

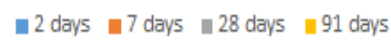

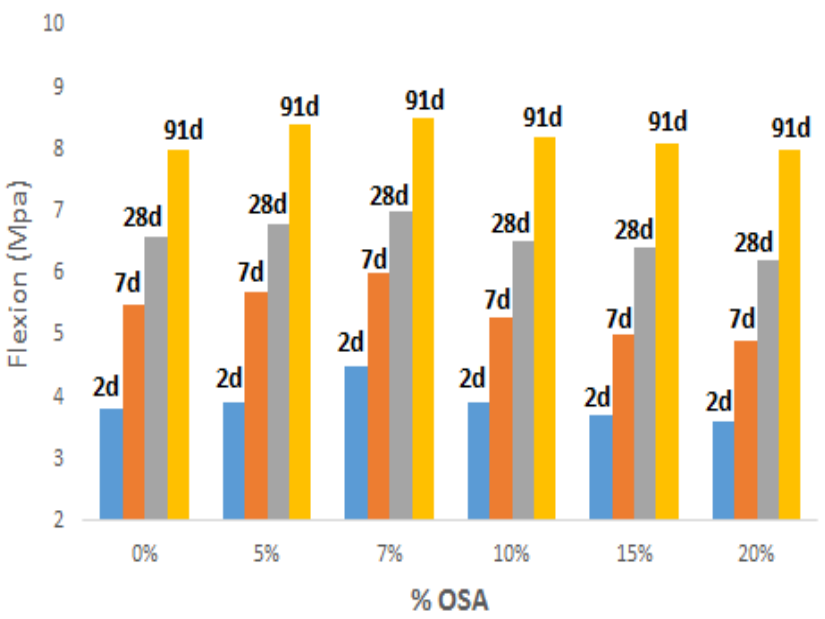

Fig.4. Bending strength of blended cement as a function of ash content.

This substitution had very good influence on the mechanical properties on the blended cement starting from early ages ( 2 and 7 days). The mechanical strengths passed through a maximum near $10 \%$ of substitution and stayed very good even with $20 \%$ of OSA. These strengths were improved considerably at 28 and 91 days for all blended cement.

\section{Acknowledgment}

The Authors express their warmest thanks to Asment Temara Plant (CIMPOR) for the technical support and to National Centre for Scientific Research (CNRST), Rabat, Morocco for their analytical instrument facilities.

\section{References}

1. L.M. Federico, S.E. Chidiac, Cem. Concr. Compos. 31 606-610 (2009)

2. W. Ladaoui, Ph.D Thesis., Uni.Tou. III P. Sabatier, (2010) (unpublished) 
3. K. Nabih, R. Barbacha, A. De la Torre, O. Sassi, K. Kada, F. Cherkaoui El-Moursli, MATEC web conf. 11 :01046 (2014)

4. M. Uibu, R. Kuusik, Jinyue Yan, Ed., 3rd IGEC, Mälardalens Uni., 1075-1085 (2007)

5. M. Uibu, and A. Trikkel, R. Kuusik, WIT. Trans. Ecol. Environ., 106 473-483 (2007)

6. A. Shogenova, S. Sliaupa, K. Shogenov, R. Vaher, R. Sliaupiene, Energy Procedia, 1 2753-2760 (2009)

7. K. Nabih, Ph.D Thesis, UM5/FSR, (1997) (unpublished)

8. NM.10.1.005, The standard technical testing of hydraulic binders (cement), (2008)

9. H.Uchikawa, 8th Int. Cong. Chem. Cem., Rio de Janeiro, 1 249-280 (1986)

10. W. Mazouzi, L. Kacimi, M. Cyr, and P. Clastres, Cem. Concr. Compo., 53 170-7 (2014)

11. R. Sersale, 7th Int Cong. Chem. Cem., Paris, IV-1/3IV-1/21 (1980)

12. R. Bouchta, O. Zemmouri, in Mines, Geo. Energy, 50 55-69 (1981)

13. A. Baron, Res. Rep. LCPC, 3-32 (1969)

14. S.N. Ude, Ph.D Thesis, UTK, (2013) (unpublished)

15. K. Nabih, N. Hamsi, Int. CMSS., MATEC web conf., 11 1-7 (2014)

16. M. Yousuf, A. Mollah, T.R., Y.N. Tsai, D.L. Cocke, Cem. Concr. Res., 23 773-784 (1993)
17. O.E. Omotoso, R. Mikular, J. Hazard. Mater., 601 128 (1198)

18. Y. Osawa, J.W. Shih, Fuel, 50 53-57 (1971)

19. S. Chomnanti, P. Deemak, A.F. Gaines, T. Kasomson, K. Keowkamned, V. Lorvldhya, C. Pomtalpong, N. Sucharitakul, V. Vanitsuksombat, W. Wiriyathien, Fuel, 49 188-196 (1970)

20. B. Čolović, V. Jokanović, N. Jović, Sci. Sinter., 45 341-350 (2013)

21. M.Y.A. Mollah, L.R. Parga, D.L. Cocke, J. Environ. Sci. Health. A., 27 1503-1519 (1992)

22. X. Ying-Mei, Q. Ji, H. De-Min, W. Dong-Mei, C. Hui-Ying, G. Jun, Z. Qiu-Min, Oil Shale, 27 37-46 (2010)

23. T. Nochaiya, Y. Sekine, S. Choopun, A. Chaipanich, J. Alloy. Comp., 630 1-10 (2015)

24. M.Y.A. Mollah, W. Yu, R. Schennach, D.L., Cocke D.L, Cem. Concr. Res., 30 267-273 (2000)

25. G.V. Rompaey, Ph.D Thesis, ULB, (2006) (unpublished)

26. A.M. Neville, 5th Ed., Harlow, Essex: Pearson Education (2011)

27. J. Yammine, Ph.D Thesis, ENS Cachan, 262, (2007) (unpublished)

28. M. Lea, 3rd Ed., London: Edward Arnold, 727 (1970) 